STUDI

FRANCESI

\section{Studi Francesi}

Rivista quadrimestrale fondata da Franco Simone

185 (LXII | II) | 2018

OCTAVE MIRBEAU: UNE CONSCIENCE AU TOURNANT

DU SIEECLE - sous la direction de Ida Merello

\title{
G. MATTEO ROCCATI, La "Josephina" de Jean Gerson et la tradition médiévale du poème biblique narratif
}

\section{Paola Cifarelli}

\section{(2) OpenEdition}

Journals

Édition électronique

URL : http://journals.openedition.org/studifrancesi/13379

DOI : $10.4000 /$ studifrancesi. 13379

ISSN : 2421-5856

Éditeur

Rosenberg \& Sellier

Édition imprimée

Date de publication : 1 août 2018

Pagination : 307-308

ISSN : 0039-2944

\section{Référence électronique}

Paola Cifarelli, « G. MATteo roccatı, La "Josephina" de Jean Gerson et la tradition médiévale du poème biblique narratif », Studi Francesi [En ligne], 185 (LXII | II) | 2018, mis en ligne le 01 août 2018, consulté le 06 janvier 2021. URL : http://journals.openedition.org/studifrancesi/13379 ; DOI : https://doi.org/ 10.4000/studifrancesi.13379

Ce document a été généré automatiquement le 6 janvier 2021 .

\section{(c)}

Studi Francesi è distribuita con Licenza Creative Commons Attribuzione - Non commerciale - Non opere derivate 4.0 Internazionale. 


\title{
G. MATTEO ROCCATI, La "Josephina” de Jean Gerson et la tradition médiévale du poème biblique narratif
}

\author{
Paola Cifarelli
}

\section{RÉFÉRENCE}

G. MATTEO RocCATI, La "Josephina" de Jean Gerson et la tradition médiévale du poème biblique narratif, «Le Moyen Âge» CXXII, fasc. 3-4, 2016, pp. 627-641.

1 Achevée en 1417 ou 1418 dans la perspective d'une diffusion auprès du public cultivé des participants au concile de Constance, la Josephina de Jean Gerson s'inscrit dans la tradition du poème narratif et des paraphrases bibliques, mais elle témoigne d'une démarche novatrice en ce qu'elle suit le schéma du poème virgilien tant pour la partition en douze chants et pour l'emploi de l'hexamètre, que pour la structuration du contenu selon l'ordo artificialis.

2 En reconstruisant le contexte culturel dans lequel le poème a été conçu, l'A. s'interroge sur la circulation, à l'époque de la composition du texte, des poèmes d'inspiration scripturaire médiévaux en hexamètres et en distiques élégiaques que le Célestin aurait pu utiliser pour la forme, ainsi que des sources d'inspiration possibles au niveau du contenu. Le Dictamen de laudibus beati Joseph de Pierre Poquet et la tradition iconographique des histoires de la Vierge constituent «la toile de fond de l'œuvre gersonienne» (p.638), mais la dimension littéraire de celle-ci, inspirée d'un modèle profane de l'antiquité classique et de l'Africa de Pétrarque, ainsi que le choix d'un personnage mineur pour construire une œuvre théologique sur la Vierge et le Christ, donnent la dimension de l'originalité de la Josephina. 